\title{
Pengembangan Perangkat Pembelajaran Matematika Materi Pengolahan Data Berbasis Pendekatan PMRI
}

\author{
Gede Sarwa Merta Dana Winaya ${ }^{1 *}$, I Ketut Dibia ${ }^{2}$, Ni Wayan Rati ${ }^{3}$ iD \\ 1,2,3 Program Studi Pendididkan Guru Sekolah Dasar, Universitas Pendidikan Ganesha, Bali, Indonesia \\ *Corresponding e-mail: sarwamerta98@gmail.com
}

\begin{abstract}
Abstrak
Prangkat pembelajaran yang digunakan oleh guru sering tidak cocok maupun belum tepat sasaran dalam suatu penerapannya. Mengingat hal tersebut dirasa perlu untuk mengembangkan perangkat pembelajran berbasis Pendekatan Pendidikan Matematika Realistik Indonesia (PMRI) untuk dapat diterapkan dalam melaksanakan proses pembelajaran di SD. Penelitian ini bertujuan untuk mengembangkan perangkat pembelajaran PMRI pada mata pelajaran matematika meteri pengolahan data siswa kels V SD. Penelitian pengembangan ini menggunakan model 4D dengan tahapan yaitu: Pendefinisian, Perancangan, Pengembangan, penyebarluasan. Instrument yang digunakan untuk mengukur tingkat validitas perangkat pembelajaran adalah rating scale berupa lembar penilaian ahli. Metode yang digunakan dalam pengumpulan data penelitian ini adalah metode kuesioner dengan menggunakan teknik analisis data kuantitatif dan kualitatif. Kegiatan uji coba menghasilkan data berupa angka yang dihitung nilai rata-rata kemudian dikonversikan dengan tabel PAP skala lima. Hasil penelitian ini adalah 1) perangkat pembelajaran PMRI mata pelajaran matematika pada materi pengolahan data meliputi RPP dan LKPD, 2) produk ini sudah divalidasi oleh ahli matematika, ahli asesmen pembelajaran dan dua orang guru kelas V dari SD yang berbeda. Nilai dari empat orang ahli perangkat RPP mendapatkan skor 4,33 dan perangkat LKPD skor 4,32, sehingga dikategorikan sangat baik. Implikasi dari penelitian ini adalah perangakat pembelajaran matematika materi pengolahan data berbasis pendekatan PMRI yang teruji validitas isinya dan siap untuk digunakan.
\end{abstract}

Kata kunci: PMRI, Matematika, Prangkat Pembelajaran.

\section{Abstract}

The learning tools used by the teacher are often not suitable or not on target in a material solution. Given this, it is deemed necessary to develop learning tools based on the Indonesian Realistic Mathematics Education Approach (PMRI) to be applied in implementing the learning process in elementary schools. This study aims to develop PMRI learning tools in mathematics subject matter data processing for students of class V SD. This development research uses a $4 D$ model with stages, namely: Define, Design, Development, Disseminate. The instrument used to measure the validity level of the learning device is a rating scale in the form of an expert assessment sheet. The method used in data collection in this study is a questionnaire method using quantitative and qualitative data analysis techniques. The trial activity resulted in data in the form of numbers which were calculated as the average value then converted to a five-scale PAP table. The results of this study are 1) PMRI learning tools for mathematics subjects in data processing materials including RPP and LKPD, 2) this product has been validated by mathematics experts, learning assessment experts and two fifth grade teachers from different elementary schools. The scores of the four lesson plan instrument experts get a score of 4.33 and the LKPD instruments score 4.32, so they are categorized as very good. The implication of this research is that mathematics learning tools data processing materials based on PMRI approach are tested for their validity and are ready to use.

Keywords: PMRI, mathematics, learning tools

\section{Introduction}

Sekolah dasar merupakan suatu tempat untuk siswa menuntut ilmu. Di sekolah dasar siswa akan mendapatkan materi yang paling mendasar. Salah satu pelajaran yang didapatkan siswa di sekolah dasar adalah matematika. Matematika sebagai satu ilmu pengetahuan yang memberikan kesempatan kepada peserta didik untuk melatih kemampuan yang meliputi: kemampuan berpikir kritis, logis, dan sistematis. Hal ini sejalan dengan pandangan (Japa,

$\begin{array}{ll}\text { History: } & \text { Publisher: Undiksha Press } \\ \text { Received }: 5 \text { August } 2020 & \text { Licensed: This work is licensed under } \\ \text { Revised } \quad: 10 \text { September } 2020 & \text { a Creative Commons Attribution 3.0 License } \\ \text { Accepted : } 26 \text { October } 2020 & \\ \text { Published : } 1 \text { Desember } 2020 & \end{array}$


2014) yang meyatakan bahwa peserta didik dibelajarkan matematika dengan tujuan untuk memperoleh beberapa kemampuan, seperti: kemampuan berpikir kritis dan kreatif, logis, sistematis, analisis, dan kemampuan bekerja sama. (Siagian, 2015) menyatakan bahwa mata pelajaran matematika penting dibelajarkan karena dalam kehidupan sehari-hari tidak terlepas dari permasalahan matematika, yang pemecahannya melalui pengaplikasian konsep matematika dan kesadaran tentang nilai-nilai yang secara esensial. Adapun tujuan pembelajaran matematika menurut (Binjai, 2019) yaitu: melatih kemampuan peserta didik dalam menemukan solusi atau konsep untuk memecahkan permasalahan, peserta didik mampu menyampaikan gagasan yang disampaikan dalam bentuk konsep matematika dan, peserta didik mampu mengembangkan pengatahuannya dalam kehidupan sehari-hari yang tidak terlepas dari permasalahan matematika. Sedangkan Depdiknas (dalam Suarjana, 2016) menyatakan tujuan diajarkan matematika di sekolah dasar agar peserta didik memiliki kemampuan yaitu: a) Memahami konsep matematika untuk dapat diaplikasikan ke konsep atau logaritma secara tepat. b) Memecahkan masalah, yang pertama harus paham terhadap masalah, merancang model matematika, menyelesaikan dalam bentuk model atau penapsiran matematika yang digunakan.

Mengingat hal tersebut harapan pemerintah maupun guru untuk siswa adalah siswa mampu mendapatkan atau mencapai hasil belajar matematika yang maksimal atau diatas ratarata. Tetapi faktanya, kemampuan matematika peserta didik masih tergolong rendah. Hasil survei Trends in International Mathematics and Science Study (TIMSS) tahun 2015 menunjukan bahwa, rata-rata skor matematika siswa Indonesia adalah 397, hal ini menyebabkan Indonesia berada pada peringkat 45 dari 50 negara yang ikut serta (Susanti \& Syam, 2017). Sedangkan hasil survei Program for International Studen Assessment (PISA) tahun 2018 (Hewi \& Shaleh, 2020) menjelaskan khususnya untuk kategori matematika, Indonesia berada pada peringkat 73 dari 80 negara yang mengikuti program ini dengan skor rata-rata 379. Skor rata-rata indonesia masih sangat jauh bila dibandingkan dengan Cina yang berada pada pringkat pertama dengan skor 591. Berdasarkan studi dokumen yang dilakukan di SD Negeri 3 Songan pada tanggal 20 September 2019, diketahui bahwa masih ada siswa mengalami kendala dalam menerima materi yang diajarkan, sehingga hasil belajar matematika sangat jauh dengan apa yang diharapkan. Selain itu, cara guru mengajar juga monoton sehingga proses pembelajaran di kelas kurang menarik. Wali kelas V menyatakan penyebab hasil belajar siswa yang rendah dipengaruhi beberapa faktor diantaranya: perangkat pembelajaran yang digunakan belum tepat sasaran dalam pemecahan materi, guru melaksanakan proses pembelajaran sudah menerapkan beberapa pendekatan dan metode yang ada, guru masih kurang dalam menerapkan pendekatan yang berpariasi untuk dapat membangkitkan motivasi belajar siswa. Melihat hal tersebut maka dirasa perlu untuk mencarikan solusi agar siswa mampu dengan mudah untuk mencerna atau memahami materi atau ilmu matematika yang mendasar. Solusi yang dapat diajukan dari permasalahan yang telah dijelaskan adalah mengembangan perangkat pembelajaran berbasis Pendekatan Pendidikan Matematika Realistik Indonesia (PMRI) untuk dapat diterapkan dalam melaksanakan proses pembelajaran di SD.

Perangkat pembelajaran merupakan alat atau bahan persiapan guru sebelum mengajar peserta didik. ( Fauzi \& Ratnawulan, 2012) menyatakan bahwa perangakat pembelajaran merupakan suatu bahan atau alat yang dugunakan sebagai perencanaan proses pembelajaran. (Susilowati \& Indriyanti, 2012) menyatakan bahwa perangkat pembelajaran adalah segala alat maupun bahan yang dipakai guru dalam melaksanakan proses pembelajaran. (Tanjung, \& Nababan, 2018) menyatakan bahwa perangkat pembelajaran merupakan sekumpulan alat-alat yang digunakan dalam proses belajar mengajar, yang meliputi silabus, RPP, LKPD, modul, bahan ajar dan buku. Berkaitan dengan pengembangan perangka pembelajaran penelitian ini akan mengembangkan RPP dan LKPD yang dipadukan dengan pendekatan (PMRI), untuk 
mengarahkan proses pembelajaran yang menuntut siswa berpikir dan beraktifitas dengan dunia nyata atau kongkrit. Susetya, (2017) menyatakan perencanaan pembelajaran merupakan langkah yang sangat penting sebelum pelaksanaanpembelajaran. Perencanaan yang matang diperlukan supaya pelaksanaan pembelajaran berjalan secara efektif. Siregar, et.al, (2019) menyatakan bahwa RPP adalah suatu program perencanaan yang disusun dan dijadikan pedoman setiap kegiatan proses pembelajaran. RPP dijabarkan dari silabus untuk mengarahkan peserta didik dalam mencapai kompetensi dasar (KD). Sedangkan Dewi, (2017) menyatakan bahwa LKPD merupakan lembaran-lembaran yang berisi tugas-tugas untuk menguji kemampuan siswa dalam memahami materi yang sudah disampaikan oleh guru. Sedangkan (Anggraini, \& Anwar, 2016) menyatakan penggunaan LKPD merupakan salah satu cara yang membantu peserta didik untuk lebih aktif mengkonstruk pengetahuannya sesuai tuntutan dalam kurikulum yang berlaku.

Mengingat Usia anak SD dalam tahapan perkembangan menurut Jean Piaget yang dikutip oleh (Suarjana, 2016) merupakan tahap oprasional kongkrit (7-12 tahun). Dimana usia anak SD belum bisa berpikir kongkrit dalam menyelesaikan suatu permasalahan. Untuk itu pendekatan Pendidikan Matematika Realistik Indonesia (PMRI) merupakan suatu pendekatan yang paling efektif digunakan di SD (Anisa, 2014). Pendekatan Pendidikan Matematika Realistik Indonesia (PMRI) juga dapat mengubah pikiran siswa SD dari abstrak menjadi nyata (real). Andriani (dalam (Gustina, \& Syahrilfuddin, 2019) menyatakan Pendidikan Matematika Realistik Indonesia (PMRI) merupakan pendekatan yang dikembangkan tahun 1971 oleh sekelompok ahli matematika sekolah yang melaksanakan dengan menempatkan realita dan pengalaman siswa sebagai titik awal pembelajaran. Sedangkan (Rahmawati, 2015) menyatakan Pendidikan Matematika Realistik Indonesia (PMRI) adalah suatu teori dalam pendidikan matematika di Indonesia yang dikembangkan pertama kali di negeri Belanda.

Pendekatan Pendidikan Matematika Realistik Indonesia (PMRI) menuntut siswa agar lingkungan bermain dapat dijadikan bahan pembelajaran yang kongkrit. Untuk dapat menerapkan pendekatan dengan baik diperlukan pengembangan perangkat pembelajaran upaya meningkatkan interaksis proses belajar mengajar dengan baik (Oftiana, Siti., 2017) Dalam mengembangkan perangkat pembelajaran berbasis Pendekatan Pendidikan Matematika Realistik Indonesia (PMRI) dikembangkan melalui RPP dan LKPD. Hal tersebut didukung oleh penelitian dari (Rahayu, 2018) yang menyatakan dengan pemberian LKPD kepada siswa, siswa akan merasa senang dan semangat dalam mengerjakan LKPD, karena di dalam LKPD terdapat masalah-masalah yang merangsang otak siswa untuk berpikir kritis. Sedangkan (Suriyanti, 2013) Siswa akan lebih paham dan mengingat pembelajaran dengan jangka panjang melalui LKPD yang diberikan oleh guru. Hal tersebut juga sejalan dengan penelitian dari Hal tersebut juga sesuai dengan peraturan mentri Pendidikan dan Kebudayaan RI No 65 Tahun 2013 (dalam (Rajabi, 2015) perangkat pembelajaran dirancang dalam bentuk silabus dan RPP yang sesuai dengan Standar isi. Sedangkan pendapat dari (Amir, 2015) penggunaan perangkat pembelajaran yang tepat sangat berpengaruh bagi proses pembelajaran di kelas untuk dapat mempasilitasi kebutuhan belajar siswa supaya belajar menjadi menarik dan menyenangkan.

Berdasarkan kondisi tersebut, maka dilakukan suatu penelitian pengembangan yang berjudul Pengembangan perangkat pembelajaran matematika materi pengolahan data berbasis pendekatan pendidikan matematika realistik Indonesia (PMRI) kelas V SD. Tujuan penelitian ini adalah untuk mengembangkan perangkat pembelajaran matematika pada materi pengolahan data berbasis pendekatan PMRI yang teruji validitas isinya. 


\section{Materials and Methods}

Desain penelitian yang digunakan dalam penelitian ini adalah penelitian pengembangan research development. Menurut Sugiyono (dalam Hidayah, 2017) research development bisa didefinisikan sebagai metode penelitian yang secara sengaja, sistematis, bertujuan/diarahkan untuk mencaritemukan, merumuskan, memperbaiki, mengembangkan, menghasilkan, menguji keefektifan produk, model, metode/strategi/cara, jasa, prosedur tertentu yang lebih unggul, baru, efektif, efesien, produktif, dan bermakna. Menurut (Borg, W.R. \& Gall, 2003), penelitian dan pengembangan adalah "A process used develop and validate educational product". (Setyosari, 2013) mengungkapkan Penelitian dan pengembangan ini kadang kala disebut juga sebagai suatu pengembangan berbasis pada penelitian atau disebut juga research-based development.

Produk atau prangkat yang dikembangkan berupa RPP dan LKPD. Perangkat yang dikembangkan diuji oleh empat ahli yaitu ahli pembelajran matematika, ahli pembelajaran dan dua orang guru SD kelas $\mathrm{V}$ dari sekolah yang berbeda. Tujuan metode penelitian pengembangan ini digunakan untuk menghasilkan produk tertentu dalam menguji keefektifan dan kemenarikan, kemudahan dan kemanfaatan produk, serta mengetahui bagaimana tanggapan siswa terhadap produk yang dikembangkan (Sunantri, A., Suyatna, A., \& Rosidin, 2016).

Pengembangan instrumen dilakukan dengan menggunakan model pengembangan 4D (four-D model) oleh Thiagarajan yang meliputi tahap mendefinisikan/membatasi (define), merancang (design), mengembangkan (develop), dan menyebarluaskan (desseminate) (Sugiyono, 2011) Pada tahap penyebar luasan tidak dilaksanakan dikarenakan situasi pandemic covid-19.

Pendefinisian (Define), tahapan pendefinisian ini didasari kebutuhan-kebutuhan pembelajaran berdasarkan analisis. Tahapan dari pendefinisian meliputi kegiatan sebagai berikut.1) Analisis awal, Pada analisis awal bertujuan untuk menetapkan masalah pada pengembangan perangkat pembelajaran dan merangkum karakteristik siswa untuk mencocokan rancangan pengembangan bahan pembelajaran. 2) Analisis materi, analisis ini bertujuan untuk menemukan kekurangan dalam hasil penyajian materi yang disampaikan oleh gurunya. 3) Analisis tugas, analisis ini dilakukan untuk menganalisis tugas-tugas setelah penyampaian materi atau keterampilan-keterampilan yang dimiliki siswa. 4) Spesifikasi tujuan pembelajaran, spesifikasi tujuan pembelajaran ini dilakukan untuk merumuskan tujuan-tujuan pembelajaran didasari dari analisis tugas dan materi.

Perancangan (Design), tahapan perancangan dilakukan untuk merancang suatu perangkat pembelajaran supaya perangkat pembelajaran menjadi layak digunakan dalam proses pembelajaran. Pengembangan (Develop), Tujuan dari tahapan pengembangan, supaya menghasilakn produk yang telah di desain menghasilkan draf produk, melakukan uji validasi produk, melakukan uji coba produk. Subjek dari penelitian ini adalah perangkat pembelajaran PMRI yang diuji coba oleh ahli yang sudah ditentukan. Ahli pembelajaran matematika dan asesmen pembelajaran berasal dari dosen yang sudah berpengalaman dibidangnya dan dari pihak 2 guru di SD yang berbeda.

Metode pengumpulan data yang digunakan dalam penelitian ini adalah metode kuisioner. Menurut (Mania, 2008) metode kuesioner merupakan daftar pertanyaan yang harus diisi oleh responden untuk memperoleh suatu informasi. Pada dasarnya kuesioner adalah sebuah daftar pertanyaan yang harus di isi oleh orang yang akan diukur (responden) (Nugroho, A. A., Putra, R. W. Y., Putra, F. G., \& Syazali, 2017). Dengan kuesioner ini dapat diketahui tentang keadaan/data diri, pengalaman, pengetahuan sikap atau pendapatnya dan lain-lain (Arikunto, 1984). Instrumen pengumpulan data adalah alat ukur yang sudah dirancang untuk mengukur objek yang akan diamati. Instrument yang akan digunakan yaitu rating scale berupa lembar penilaian yang diuji oleh ahli, yaitu ahli matematika dan guru 
kelas. Untuk memastikan validitas intrumen dilakukan beberapa kegiatan yaitu 1) membuat Tabel kisi-kisi, 2) konsultasikan dengan dosen pembimbing, 3) menuliskan instrument, 4) Melakukan uji validitas isi.

Data yang dikumpulkan adalah hasil validitas dan masukan oleh para ahli. Data yang diperoleh adalah data kualitatif yaitu masukan, saran dan komentar dari semua validator, data kuantitatif yaitu skor yang diperoleh melalui instrumen dari lembar penlilaian. Jenis data yang dikumpulkan adalah hasil review dari ahli pembelajaran matematika, ahli pembelajaran dan 2 orang guru kelas V dari SD yang berbeda. Setelah data dikumpulkan selanjutnya diuji validitas isi dan uji validitas butir.

\section{Results and Discussion}

\section{Hasil penelitian}

Penelitian ini menghasilkan perangkat pembelajaran PMRI pada mata pelajaran matematika di SD kelas V mendapatkan hasil valid. Validnya suatu perangkat pembelajaran setelah melakukan kegiatan pengembangan dan validitas instrumen. Penyajian data hasil uji coba, akan dipaparkan melalui model yang digunakan dalam penelitian pengembangan yaitu model pengembangan 4D sebagai berikut.

Define Pendefinisian dilakukan untuk mengetahui informasi, situasi dan kondisi yang ada di lapangan. Hasil wawancara yang dilakukan di SD 3 Songan kecamatan Kintamani kabupaten Bangli, sekolah belum mempunyai perangkat pembelajaran matematika. Berdasarkan pencatatan dokumen pada daftar nilai, pengetahuan siswa pada pembelajaran matematika masih banyak yang belum mencapai KKM yang ditentukan, sehingga perlu dirancang perangkat pembelajaran untuk aktivitas siswa yang baik. Analisis kurikulum dilakukan untuk mengetahui kompetensi dasar dan indikator pada materi pengolahan data matapelajaran matematika kelas V semester II.

Design (Perancangan) yang dimaksud adalah merancang sebuah perangkat prototype. Perangkat pembelajaran yang akan dirancang terdiri dari RPP dan LKPD berdasarkan informasi yang didapatkan sebelumnya. Adapun Rancangan pelaksanaan pembelajaran (RPP) didesain seperti berikut. 1). Identitas RPP memuat nama sekolah yang menggunakan RPP, mata pelajaran, kelas, semester, materi pokok, dan alokasi waktu. 2) Kompetensi Dasar (KD) yang digunakan dalam RPP sesuai dengan Permendikbud Nomor 24 Tahun 2016. Pembelajaran matematika kelas V materi pengolahan data, terdapat kompetensi dasar. 3) Indikatator pada RPP yang dibuat, dirumuskan dari KD yang sesuai dari Permendikbud Nomor 24 Tahun 2016. 4) Tujuan pembelajaran dirumuskan sesuai dengan indikator dan langkah-langkah kegiatan pembelajaran PMRI. 5) Materi pembelajaran disesuaikan dengan indikator yang telah dijabarkan dari KD dan tujuan pembelajaran yang telah dirumuskan. 6) Pendekatan pembelajaran, menggunakan pendekatan PMRI dan metode yang digunaka menggunakan metode tanyajawab dan penugasan. 7) Media yang digunakan, melalui LKPD yang sudah dirancang dalam RPP. 8) Langkah-langkah pembelajaran memuat pendahuluan, inti dan penutup. 9) Penilaian hasil belajar meliputi tiga penilaian yaitu: penilaian kognitif, penilaian afektif, dan penilaian psikomotor.

Sedangkan desain lembar kerja peserta didik (LKPD) adalah sebagai berikut. 1) Identitas LKPD memuat mata pelajaran, kelas dan semester serta nama yang tergabung dalam kelompok siswa. 2) Petunjuk LKPD digunakan untuk petunjuk penggunaan LKPD. 3) Tujuan pembelajaran harus sesuai dengan indikator yang akan dicapai pada RPP. 4) Kesesuaiaan materi dengan tujuan pembelajaran yang ada di LKPD. 5) Kegiatan LKPD sesuai dengan langkah- pembelajaran PMRI. 6) Penugasan yang diselesaikan dalam LKPD, dikerjakan secara berkelompok tetapi dapat dipertanggung jawabkan secara individu. 
Develop (pengembangan) ketiga ini dilakukan melalui dua tahapan yaitu; (1) penilaian ahli, langsung diberikan hasil sekaligus revisi produk, (2) uji coba pengembangan. Untuk mengetahui hasil penilaian ahli yang dilakukan penilaian ahli matematika, ahli pembelajaran dan dua orang guru SD yang berbeda. Hasil uji coba perangkat pembelajaran dari empat orang penguji, dilakukan analisis data dengan mencari rata-rata setiap komponen perangkat pembelajaran. Kemudian dikonversikan dengan table PAP skala lima.

Berdasarkan analisis data perangkat rencana pelaksanaan pembelajaran (RPP) terdapat rentangan table konversi PAP skala lima nilai rata-rata di 4,01 $<\mathrm{x} \leq 5,01$ "sangat baik". Rata-rata nilai RPP mendapatkan hasil 4,33. Sedangkan rangkuman skor uji coba LKPD dari empat orang penguji, analisi data untuk mengetahui rata-rata skor dari setiap komponen LKPD, kemudian dikonversikan dengan table PAP skala lima, ehingga diperoleh hasil antara 4,01 $<\mathrm{x} \leq 5,01$ memiliki kualifikasi "sangat baik". Rata-rata nilai LKPD adalah 4,32 .

\section{Pembahasan}

Penelitian pemngembangan perangkat pembelajaran PMRI dilaksanakan pada tanggal 03 Agustus 2020 meliputi RPP dan LKPD pada kelas V SD semester genap. Pengembangan perangkat pembelajaran PMRI menggunakan model 4D sebagai tahapan dalam pengembangan. Prototype Model 4D meliputi tahapan yaitu: 1) Define (pendefinisian), 2) Design (perancangan), 3) Develop (pengembangan). Selanjutnya pengembangan perangkat pembelajaran yang telah diuji oleh empat orang ahli juga akan memuat revisi produk berdasarkan saran, komentar dan masukan dari keempat orang ahli. Kegiatan ini bertujuan untuk menyempurnakan produk yang telah dikembangkan kedepannya. Sehingga perangkat pembelajaran tersebut maksimal untuk gunakan. Kegiatan pembelajaran menuntut guru melakukan persiapan yang lebih matang dalam penerapannya, karena perangkat pembelajaran PMRI merupakan jenis perangkat pembelajaran yang melibatkan pembelajaran yang baru. Penelitian (Tuerah, 2017) bahwa terdapat pengaruh pendekatan pendidikan matematika realistik Indonesia terhadap hasil belajar matematika pada pokok bahasan garis dan sudut. Hal tersebut dikarenakan sebelum memuali pembelajaran guru sudah siap dengan pembelajaran maupun perangkat pembelajaran yang akan dibelajarkan pada saat pelajaran akan berlangsung. Dalam penerapan pendekatan ini, guru harus lebih tegas dalam pembagian kelompok supaya pembagiannya heterogen. Pendekatan PMRI melibatkan kegiatan pembelajaran dengan dunia nyata atau real, sehingga memerlukan waktu yang cukup lama. Menanggulangi keperluan waktu yang cukup lama pembelajaran menggunakan pendekatan PMRI dengan mengatur diskusi diharuskan tepat waktu yang telah ditentukan dan membatasi jumlah soal yang diberikan.

Perangkat pembelajaran merupakan alat atau bahan persiapan guru sebelum mengajar peserta didik. ( Fauzi \& Ratnawulan, 2012) menyatakan bahwa perangakat pembelajaran merupakan suatu bahan atau alat yang dugunakan sebagai perencanaan proses pembelajaran. (Susilowati \& Indriyanti, 2012) menyatakan bahwa perangkat pembelajaran adalah segala alat maupun bahan yang dipakai guru dalam melaksanakan proses pembelajaran. (Tanjung, \& Nababan, 2018) menyatakan bahwa perangkat pembelajaran merupakan sekumpulan alat-alat yang digunakan dalam proses belajar mengajar, yang meliputi silabus, RPP, LKPD, modul, bahan ajar dan buku. Berkaitan dengan pengembangan perangka pembelajaran penelitian ini akan mengembangkan RPP dan LKPD yang dipadukan dengan pendekatan (PMRI), untuk mengarahkan proses pembelajaran yang menuntut siswa berpikir dan beraktifitas dengan dunia nyata atau kongkrit. Susetya, (2017) menyatakan perencanaan pembelajaran merupakan langkah yang sangat penting sebelum pelaksanaanpembelajaran. Perencanaan yang matang diperlukan supaya pelaksanaan pembelajaran berjalan secara efektif. Siregar, et.al, (2019) menyatakan bahwa RPP adalah suatu program perencanaan yang disusun dan 
dijadikan pedoman setiap kegiatan proses pembelajaran. RPP dijabarkan dari silabus untuk mengarahkan peserta didik dalam mencapai kompetensi dasar (KD). Sedangkan Dewi, (2017) menyatakan bahwa LKPD merupakan lembaran-lembaran yang berisi tugas-tugas untuk menguji kemampuan siswa dalam memahami materi yang sudah disampaikan oleh guru. Sedangkan (Anggraini, \& Anwar, 2016) menyatakan penggunaan LKPD merupakan salah satu cara yang membantu peserta didik untuk lebih aktif mengkonstruk pengetahuannya sesuai tuntutan dalam kurikulum yang berlaku.

\section{Conclusion}

Berdasarkan rumusan masalah dan hasil penelitian dapat disimpulkan bahwa, rata-rata nilai perangkat pembelajran PMRI yang dikonversikan dalam tabel PAP skala lima RPP mendapatkan skor 4,33 kualifikasi "sangat baik" dan LKPD mendapatkan skor 4,32 kualifikasi "sangt baik". Dengan demikian, pengembangan perangkat pembelajaran PMRI pada materi pengolahan data kelas V SD menghasilkan kualifikasi sangat baik dan cocok untuk diterapkan di sekolah dasar. Adapun saran yang dapat disampaikan berdasarkan hasil penelitian pengembangan perangkat pembelajaran adalah sebagai berikut. Kepala sekolah diharapkan mampu memfasilitasi guru utuk mengembangkan perangkat pembelajaran sejenis, supaya dapat memberikan kontribusu positif terhadap kemajuan proses pembelajarannya sehingga mendukung peningkatan kualitas kemajuan sekolah. Guru diupayakan dapat menggunakan perangkat pembelajaran PMRI untuk diterapkan dalam proses pembelajaran pada materi pengolahan data di kelas V SD. Kepada penelitilain. Penelitian ini dapat dijadikan suatu referensi mengenai pengembangan perangkat pembelajaran. Tetapi diharapkan dapat mengeksplorasi dari sumber yang beragam sebagai pertimbangan produk yang sejenis.

\section{References}

Amir, M. (2015). Pengembangan Perangkat Pembelajaran Berbasis Pengalaman Pada Peserta Didik Kelas XI IPA SMA Negeri 9 Pinrang. Jurnal Sains Dan Pendidikan Fisika, 11(3). https://doi.org/https://doi.org/10.35580/jspf.v11i3.1756

Anggraini, Yenny Anwar, K. M. (2016). Pengembangan Lembar Kerja Peserta Didik (LKPD) Berbasis Learning Cycle 7E Materi Sistem Sirkulasi Pada Manusia Untuk Kelas XI SMA. Jurnal Pembelajaran Biologi, 3(1). https://doi.org/https://doi.org/10.36706/fpbio.v3i1.4956

Anisa, W. . (2014). Peningkatan Kemampuan Pemecahan Masalah Dan Komunikasi Matematika Melalui pembelajaran Pendidikan Matematika Realistik. Jurnal Pendidikan Dan Keguruan, 1(1). https://doi.org/https://doi.org/10.37058/jp3m.v1i1.147

Arikunto, S. (1984). Dasar-Dasar Evaluasi Pendidikan. Bina Aksara.

Binjai, S. B. (2019). Pengaruh Model Pembelajaran Problem Based Learning Terhadap Kemampuan Komunikasi Matematis Siswa Kelas VIII SMP Negeri 2 Salapian Kabupaten Langkat Tahun Pelajaran 2018/2019. Jurnal Serunai Ilmu Pendidikan, (Online), 5(1). https://doi.org/https://doi.org/10.37755/sjip.v5i1.154

Borg, W.R. \& Gall, M. . (2003). Educational Research : an Introduction. Longman.

Chodijah, S., Fauzi, A., \& Ratnawulan, R. (2012). Pengembangan perangkat pembelajaran fisika menggunakan model guided inquiryyang dilengkapi penilaian portofolio pada materi gerak melingkar. Jurnal Penelitian Pembelajaran Fisika, 1(1). https://doi.org/https://doi.org/10.1234/jppf.v1i1.603

Dewi, W. S. (2017). Penerapan Model Pembelajaran Hands On Mathematics Berbantuan 
Lkpd Yang Terintegrasi Pada Simbol-Simbol Keislaman Terhadap Kemampuan Berpikir Kritis Matematis Peserta Didik (Doctoral dissertation, UIN Raden Intan Lampung).

Gustina, H. T, Syahrilfuddin, dan E. N. (2019). Pengaruh Pendekatan Pendidikan matematika realistik Indonesia (PMRI) Terhadap hasil Belajar matematika Siswa kelas III SD Negeri 144 Pekanbaru. Jurnal Tunjuk Arah, 2(1), 31-32. https://doi.org/https://www.researchgate.net/deref/http\%3A\%2F\%2Fdx.doi.org\%2F10.3 1258\%2Fjta.v2i1.30-39

Hewi, L., \& Shaleh, M. (2020). Refleksi Hasil PISA (The Programme For International Student Assesment): Upaya Perbaikan Bertumpu Pada Pendidikan Anak Usia Dini. Jurnal Golden Age, Universitas Hamzanwadi, 04(1), 30-41.

Hidayah, N. (2017). Pengembangan Media Pembelajaran Berbasis Komik Pada Mata Pelajaran Ilmu Pengetahuan Sosial Kelas IV MI Nurul Hidayah Roworejo Negerikaton Pesawaran. Jurnal Pendidikan Dan Pembelajaran Dasar, 4(1). https://doi.org/https://doi.org/10.24042/terampil.v4i1.1804

Japa, I. G. N. (2014). Pengaruh pembelajaran kuantum berorientasi pemecahan masalah dalam pembelajaran matematika terhadap penalaran mahasiswa. Jurnal Ilmu Pendidikan, 20(1). https://doi.org/http://dx.doi.org/10.17977/jip.v20i1.4373

Mania, S. (2008). Teknik Non Tes: Telaah Atas Fungsi Wawancara Dan Kuesioner Dalam Evaluasi Pendidikan. Lentera Pendidikan: Jurnal Ilmu Tarbiyah Dan Keguruan, 11(1), 45-54. https://doi.org/10.24252/lp.2008v11n1a4

Minarti, I. B., Susilowati, S. M. E., \& Indriyanti, D. R. (2012). Pengembangan Perangkat Pembelajaran Ipa Terpadu Bervisi Sets Berbasis Edutainment pada Tema Pencernaan. Journal of Innovative Science Education, 1(2).

Nugroho, A. A., Putra, R. W. Y., Putra, F. G., \& Syazali, M. (2017). Pengembangan blog sebagai media pembelajaran matematika. Jurnal Pendidikan Matematika, 8(2). https://doi.org/https://doi.org/10.24042/ajpm.v8i2.2028

Oftiana, Siti., A. A. S. (2017). Pengaruh Pendekatan Pembelajaran Matematika Realistik Indonesia (PMRI) Terhadap Kemampuan Pemecahan Masalah Matematika Siswa Kelas VII SMP Negeri 2 Srandakan. Jurnal Matematika Dan Pembelajaran, 5(2), 296. https://doi.org/https://doi.org/10.24252/mapan.v5n2a10

Rahayu, D. (2018). Pengembangan Lembar Kerja Peserta Didik (LKPD) Berbasis Pemecahan Masalah Materi Bangun Datar. Jurnal Penelitian Pendidikan Guru Sekolah Dasar, 6(3). https://doi.org/https://jurnalmahasiswa.unesa.ac.id/index.php/jurnal-penelitianpgsd/article/view/23506

Rahmawati, dyah \& P. (2015). Keefektifan Pembelajaran dengan Pendekatan Pendidikan Matematika Realistik (PMRI) pada kemampuan Pemecahan Masalah Pokok Bahasan Segiempat di MTS Negeri 1 Palembang. Jurnal Pendidikan Matematika JPM RAFA, $1(1)$.

Rajabi, M. (2015). Pengaruh Perangkat Pembelajaran Instalasi System Operasi Dengan Model Pembelajaran Berbasis Proyek. Jurnal Pendidikan, 3, 49.

Setyosari, P. (2013). Metode Penelitian Pendidikan \& Pendidikan. Prenadamedia Group.

Siagian, R. E. F. (2015). Pengaruh Minat dan Kebiasaan Belajar Siswa Terhadap Prestasi Belajar Matematika. Formatif: Jurnal Ilmiah Pendidikan MIPA, (Online), 3(2). https://doi.org/http://dx.doi.org/10.30998/formatif.v2i2.93 
Siregar, E. A., Daulay, F. S., Lubis, S., Mintaito, P., \& Yulianita, R. (2019). Merancang RPP Tematik SD/MI Sesuai Kurikulum 2013.

Suarjana, I. M. \& K. S. (2016). Pendidikan Matematika I.

Sugiyono. (2011). Metode Penelitian Pendidikan Pendekatan Kuantitatif, Kualitatif, dan $R \& D$. Alfabeta.

Sunantri, A., Suyatna, A., \& Rosidin, U. (2016). Pengembangan Modul Pembelajaran Menggunakan Learning Content Development System Materi Usaha dan Energi. Jurnal Pembelajaran Fisika, 4(1).

Suriyanti, L. S. (2013). Pengaruh Penerapan Pendekatan Pembelajaran Matematika Realistik (PMR) Terhadap Hasil Belajar Matematika pada Siswa Kelas VIII SMP Negeri 17 Kendari. Jurnal Penelitian Matematika, $\quad$ 1(1), 99. https://doi.org/http://dx.doi.org/10.36709/jppm.v1i1.2956

Susanti, E., \& Syam, S. S. (2017). Peran Guru dalam Meningkatkan Kemampuan Literasi Matematika Siswa Indonesia. Seminar Matematika Dan Pendidikan Matematika, November 2017, 1-6.

Susetya, B. (2017). Meningkatkan Kemampuan Guru dalam Menyusun Silabus dan RPP Melalui Supervisi Akademik di SD N Gambiran Yogyakarta Tahun 2016. Jurnal Taman Cendekia, 1(2). https://doi.org/http://dx.doi.org/10.30738/tc.v1i2.1944

Tanjung, H. S., \& Nababan, S. A. (2018). Pengembangan Perangkat Pembelajaran Matematika Berorientasi Model Pembelajaran Berbasis Masalah (PBM) untuk Meningkatkan Kemampuan Berpikir Kritis Siswa SMA Se-Kuala Nagan Raya Aceh. Genta Mulia: Jurnal Ilmiah Pendidikan, 9(2).

Tuerah, M. (2017). Pengaruh Pendekatan Pendidikan Matematika Realistik Indonesia Terhadap Hasil Belajar Siswa Pada Materi Pokok Bahasan Garis Dan Sudut. Jurnal Matematika, 5(2), 167. 